\title{
Minicurso 2: Flash para construções de animações
}

\author{
Anita Raquel Cestari da Silva Grando \\ Liane Margarida Rockenbach Tarouco* \\ Centro Interdisciplinar de Novas Tecnologias da Educação \\ Universidade Federal do Rio Grande do Sul
}

\section{Súmula}

O trabalho terá como objetivo apresentar o ambiente de trabalho do Flash, suas barras de tarefas, a janela de trabalho e a linha do tempo.

Explorar as ferramentas de desenho, a transformação dos mesmos e outros em símbolos e as possíveis mudanças em sua aparência.

Realizar animações, incluir e trabalhar com botões de ação e adicionar sons.

\section{Tópicos a serem abordados:}

$>$ Ambiente de trabalho

Quando abrimos o flash vemos sua área de trabalho pronta para criar animações.

Seu ambiente de trabalho se constituí de várias barras com diversas ferramentas e a opção de trabalhar com painéis

Imagem: janela do flash, ao clicar ela mostra uma maior.

$>$ Barras

$>$ Janela

$>$ Linha do tempo

\section{Desenhos}

Símbolos

Dimensionamento e rotação

Tonalidade

Alfa

Camadas

Som

Animações

\section{Interpolação de movimento}

Interpolação de formas

> Interpolação de cores

$>$ Trajetória de movimento

Botões

\footnotetext{
* Doutora em Engenharia Elétrica pela USP e Mestre em Ciência da Computação pela UFRGS
} 
Botões da biblioteca

Construção de botões

\section{Metodologia}

O material será apresentado em HTML com animações e exemplos em Flash. Ele se constituirá de exercícios a serem executados no aplicativo Flash5. 